\title{
海面廃棄物処分場に貫入する粒状廃棄物 連込み挙動
}

\author{
野村 理樹 1 ・菊池 喜昭 2 -兵動 太- 3 ・野畑 俊介 4 ・ \\ 平尾 隆行5 - 竹本 誠 5 - 松村 聡6 \\ 1 学生会員 東京理科大学大学院理工学研究科土木工学専攻 (下278-8510 千葉県野田市山崎 2641) \\ E-mail:7617615@ed.tus.ac.jp \\ 2 フェロー会員 東京理科大学教授 理工学部土木工学科 (广⿳278-8510 千葉県野田市山崎 2641) \\ E-mail: kikuchi_y@rs.tus.ac.jp \\ 3 正会員 東京理科大学助教 理工学部土木工学科 (テ278-8510 千葉県野田市山崎 2641) \\ 4 東京理科大学 理工学部土木工学科 (下278-8510 千葉県野田市山崎 2641) \\ 5 中電技術コンサルタント(株) 都市整備部 ( $7734-8510$ 広島市南区出汐二丁目 3-30) \\ 6 正会員 国立研究開発法人 海上・港湾・航空技術研究所 (
}

\begin{abstract}
海面廃棄物処分場跡地を高度利用する際には，構造物を支持する基礎工として支持地盤への杭打設が 必要となると考えられ, その場合, 遮水基盤(粘性土地盤)を貫通するような杭の施工が必要である. 杭を 打設した場合には廃棄物を遮水基盤以下へ連れ込むこと䀣念される. 本研究では, 杭の肉厚と廃棄物の 粒径の大小関係の違いによる連れ込みメカニズムの違いから，小粒径の廃棄物については，廃棄物層と その下の粘性土層の剛性の違いによる廃棄物の連れ込夕状況に及ぼす影響を検討した。 大粒径の廃棄物 については杭から受ける力の偏心量の違いによる, 連れ込み挙動の違いを検討した. 実験の結果, 小粒 径の廃棄物では粘性土地盤の剛性が相対的に低下寸ることで廃棄物の連込み量は増加すること, 大粒径 の廃棄物については偏心量が異なると連れ込多深さが異なることがわかった.
\end{abstract}

Key Words : use of landfill, pile foundation, X-rayCT analysis, offshore controlled waste landfill

\section{1. はじめに}

わが国では，大規模な管理型廃棄物処分場が数多く建 設されている．これらは，建設時には沖合の処分場とし て整備されるが，港湾区域の拡大によって港湾区域内の 重要な場所に立地するようになる．そのため，処分場跡 地は将来，工業用地や交通用地として有効利用する期待 が高くなる.

管理型海面処分場の多くは遮水基盤として粘性土層を 利用しており，この場合遮水シートは用いられない。ま た, 遮水基盤としての粘性土層は遮水性を確保するため, 粘土地盤が未改良のまま利用されることが多く，構造物 の基礎を設置するには支持力が不十分となる，そこで， 処分場跡地を高度利用する場合には，何らかの地盤対策 が必要になる。しかし, サンドコンパクションパイルや サンドドレーン工法等の地盤改良では，処分場内部の廃 棄物や保有水を処分場外に排出してしまうことになるた め, 遮水基盤に対する地盤改良を行うことは困難である. そのため，地盤対策としては軟弱地盤下部の支持層への 基礎杭を打設することが妥当であると考えられる.
これまでにも, 実際の海面処分場に杭が打設された事 例が存在する 1)が，これまでの工法では，ケーシング等 によって杭周辺の廃棄物を取り除き, 杭が廃棄物を遮水 基盤層内に連れ込まない条件で施工されていた．また， 遮水基盤に貫入された杭の杭面と粘性土地盤の遮水性が 問題となる可能性があったため, その点に着目した研究 2), 3)がなされている. その結果，粘土地盤亡杭の境界面 における透水性は粘土地盤が正規圧密状態になれば非常 に低くなることが分かっている. さらに，杭打設後の保 有水の移流拡散による粘土地盤への影響は限定的である ことが分かっており，杭打設後に地震が発生した場合も 杭の存在による遮水性能の低下や処分場外二の保有水の 拡散はほとんどない4ものと考えられる.

その後, 廃棄物層を貫通して遮水基盤である粘性土地 盤に基礎杭を打設することによる廃棄物と保有水の遮水 基盤以下 $の$ 連れ込夕の課題に関する研究が行われた ${ }^{5)}$.

また，現場試験の結果から，杭打設に伴い大きな塊や ひも状の廃棄物の遮水基盤への連込みが多く確認されて おり 6，それらの廃棄物を遮水基盤へ連れ込まないよう な基礎杭の形状や打設方法の検討が必要となっている. 
そこで本研究では，管理型海面処分場に存在する廃棄 物のうち，杭の肉厚と廃棄物の粒径の大小に着目し，廃 棄物の連れ込み状況について検討した.

杭の肉厚より小さな粒状廃棄物については粘性土地盤 の圧密圧力を変えた実験を行った. これまでの研究 5)で は，あらかじめ圧密 $\left(100 \mathrm{kN} / \mathrm{m}^{2}\right)$ した模型遮水基盤(粘性土 地盤)を作製し，この圧密圧力を除去した状態で，上部に 廃棄物を模した砂層(層厚 $5 \mathrm{~cm}$ )を作製して，杭を貫入さ せて砂の下部粘性土層への連れ込みについて検討してき た.この場合には，粘性土地盤の剛性が砂地盤の剛性に 比べてはるかに大きな条件での実験となっている。しか し，実際の処分場の条件を考えたときに，仮に地表面か ら $15 \mathrm{~m}$ 程度廃棄物層があって, その下に, 正規圧密状態 の粘性土層があるとした場合，廃棄物層がほぼ砂と同じ 性状を持つ $\phi$ 材であるとすると，せん断強さ $\tau_{\mathrm{f}}$ はおよそ $150 \mathrm{kN} / \mathrm{m}^{2}$ 程度が期待できるのに対し, 廃棄物層に接して いるところの粘性土層のせん断強さ $\tau_{\mathrm{f}}$ はおよそ $30 \mathrm{kN} / \mathrm{m}^{2}$ 程度にしかならない.この時, $\mathrm{E}_{50} / \mathrm{q}_{\mathrm{u}}$ がどちらも等しいと すれば，せん断強さの違いと比例するように地盤の剛性 も異なることになり，廃充物地盤のほうが粘性土地盤よ りも剛性が高い状態であり，模型実験と実物とで大きく 条件が異なっていることになる，そこで，ここでは，で きるだけ粘性土の圧密圧力を下げることで，相対岡性を 変動させて実験をすることにより, 廃棄物層と粘性土層 の剛性比の違いが連れ込み挙動に及ぼす影響を検討した。

杭の肉厚より大きな粒状廃棄物については，杭と粒状 体の接触点の位置の違いによって粒状体の回転のしやす さが異なるであろうと考え，粒状体を板でモデル化し， 板に偏心荷重を与えることで，板の連れ込みやすさが異 なるかどうか観察することにした.

\section{2. 実験概要}

実験に用いた粘性土は「青粘土」の $106 \mu \mathrm{m}$ ふるいを通 過したものである. 物性を表-1に示す．本研究では，処 分場内に存在する廃棄物を杭の肉厚より大きなものと小 さなものの二種類に分類し，別々に実験を行った.この 2 つのケースは実験手順が異なるため分割して説明する.

\section{（1）杭の肉厚より小さな粒状廃棄物の連込み実験}

図-1 に示寸模型杭のうち(2)の杭を除いて杭軸部の肉 厚は $2 \mathrm{~mm}$ であり，これより小さな粒径をもつ廃棄物は 珪砂 5 号 $\left(\rho_{s}=2.65 \mathrm{~g} / \mathrm{cm}^{3}, \quad \mathrm{D}_{50}=0.589 \mathrm{~mm}\right)$ で模擬した. 実験 では珪砂 5 号のうち $250 \mu \mathrm{m}$ ふるいに残留したものを用 いた.これにより, 粘性土と珪砂 5 号の粒径の差別化を 図った. 図-2 に示す試験機に含水比を調整した青粘土 $(\mathrm{w}=100 \%)$ を投入し，1 日間静置させた後に所定の圧密圧
力 $\left(50,30,20,10 \mathrm{kN} / \mathrm{m}^{2}\right)$ で圧密して粘性土モデル地盤(層 厚 $\mathrm{h}=9 \mathrm{~cm}$ )を作製した. 作製したモデル地盤上部に珪砂 5 号を水中落下法にて $5 \mathrm{~cm}$ の厚さで作製した. その後，模 型杭(外径 $19 \mathrm{~mm}$, 長さ $150 \mathrm{~mm}$ ，ステンレス製)を準静的 に $8 \mathrm{~cm}$ 貫入した. 用いた杭は，図-1 に示すもので，杭 の先端形状を変えることにより，杭貫入時に粘性土より 上層にある砂がどのように粘性土層に連れ込まれるかそ の違いを観察することにした。

杭打設後に，杭先端と杭の先端から深度方向 $8 \mathrm{~mm} こ ゙$ とに杭周辺の粘土をそれぞれ採取し，106 $\mu \mathrm{m}$ ふるいを用 いて粘土と砂を分離し，深度ごとに粘性土中に連込まれ た砂の質量を計測した。ささらに，粒状廃棄物の連込み挙 動を詳しく検討するため X 線 CT 装置を使って杭貫入中 の砂の移動状況も観察した。この際には，土槽(内径 104 $\mathrm{mm}$, 高さ $\mathrm{H}=30 \mathrm{~cm})$ に含水比を調整した青粘土(w=47\%) を投入し, 1 日間静置させ地盤(層厚 $\mathrm{h}=20 \mathrm{~cm}$ )を作製した. 作製した粘性土モデル地盤の上に珪砂 3 号 $\left(\rho_{s}=2.67 \mathrm{~g} / \mathrm{cm}^{3}\right.$, $D_{50}=1.28 \mathrm{~mm}$ ）を水中落下法で $5 \mathrm{~cm}$ の厚さで敷設した. その後, 閉端杭 $(\varphi=30 \mathrm{~mm})$ を貫入速度 $5 \mathrm{~mm} / \mathrm{min}$ で準静的 に貫入し，所定の貫入深さごとにX 線 CT スキャンを行 った.

表-1 粘性土(青粘土の物性)

\begin{tabular}{|l|l|l|l|}
\hline 土粒子密度 & $2.79\left(\mathrm{~g} / \mathrm{cm}^{3}\right)$ & 塑性限界 & $24.2 \%$ \\
\hline 液性限界 & $40.1 \%$ & 塑性指数 & 15.9 \\
\hline
\end{tabular}

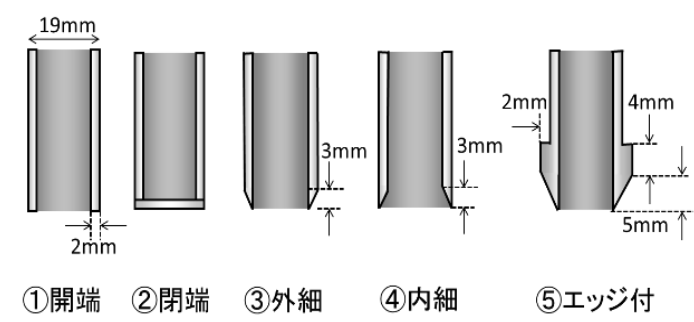

図-1 模型杭の概略

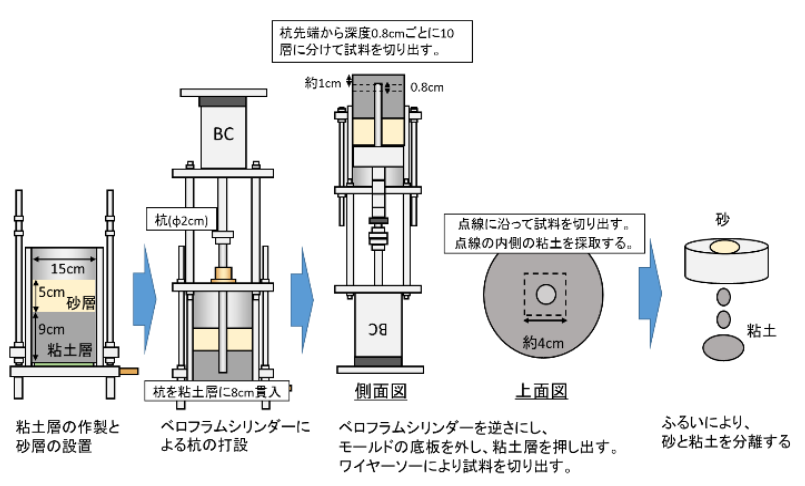

図-2 実験模式困

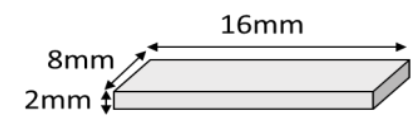

図-3 矩形金属板の模式図 


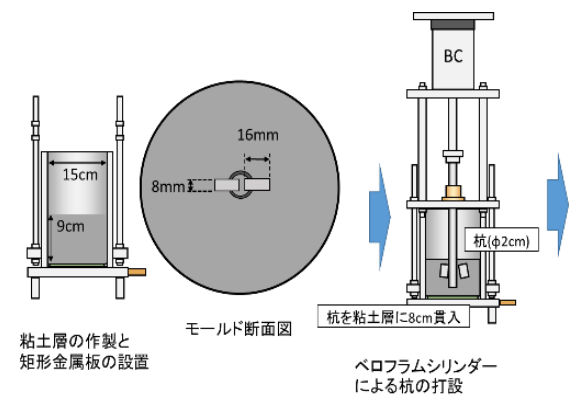

図-4 実験模式図

\section{（2）杭の肉厚より大きな粒状廃棄物の連込み実験}

肉厚より大きな粒状廃棄物は図-3 に示寸アルミ製の 矩形金属板(模型杭の肉厚の 8 倍相当)で模擬した.

ここでの実験手順を図-4に示寸. 図-4に示寸試験機に 含水比を調整した青粘土(w=100\%)を投入し，1 日間静置 させた後に圧密圧力 $50 \mathrm{kN} / \mathrm{m}^{2}$ で圧密して粘性土モデル地 盤(層厚 $\mathrm{h}=9 \mathrm{~cm}$ )を作製した. 作製した粘性土モデル地盤 の上に矩形金属板を設置し，金属板に偏心荷重を作用さ せた。ここでは荷重を作用させた位置と金属板の中心位 置の距離を偏心量と定義した(図-5)。偏心量を変化させ た複数のケースにおいて，先端形状の異なる模型杭を準 静的に $8 \mathrm{~cm}$ 貫入した. 杭打設後, 粘性土を切り出すこと で金属板の粘性土内に貫入された深さを計測した。ここ ではこのようにして，金属板の粘性土への連込みにおけ る貫入深さの違いを検討した。

杭の肉厚より大きな粒状廃棄物に関しても X 線 CT を 使った観察をした。土槽(内径 $104 \mathrm{~mm}$ ，高さ $\mathrm{H}=30 \mathrm{~cm}$ )に 含水比を調整した青粘土 $(\mathrm{w}=47 \%)$ を投入し， 1 日間静置 させた後に圧密圧力 $50 \mathrm{kN} / \mathrm{m}^{2}$ で圧密して粘性土モデル地 盤(層厚 $\mathrm{h}=20 \mathrm{~cm}$ )を作製した. 作製した粘性土モデル地盤 の上に矩形金属板を設置し，金属板の偏心量を変化させ た複数のケースを設定した．金属板の設置後，開端杭 $(\varphi=30 \mathrm{~mm}$ ，肉厚 $1.5 \mathrm{~mm})$ を静的に貫入した. その際に, 所定の貫入深さごとに X 線 CT スキャンを行い，杭貫入 による模擬廃棄物層の連込み挙動を調べた。

\section{3. 実験結果}

\section{(1)杭の肉厚より小さな粒状廃棄物の連込み}

まず，圧密圧力の違いにより杭貫入に伴う粘性土に連 込まれた砂の総質量がごのように変化するのかを検討し た．粘性土地盤を作製する際の圧密圧力と粘性土に連込 まれた砂の連込み量の総和の関係を図-6に示寸. 四角の プロットが閉端杭を用いた場合の砂の連込み量を示し， 菱形，下三角，上三角のプロットはそれぞれ開端杭，外 細杭，エッジ杭を用いた場合の連込久量を示す．図-6よ

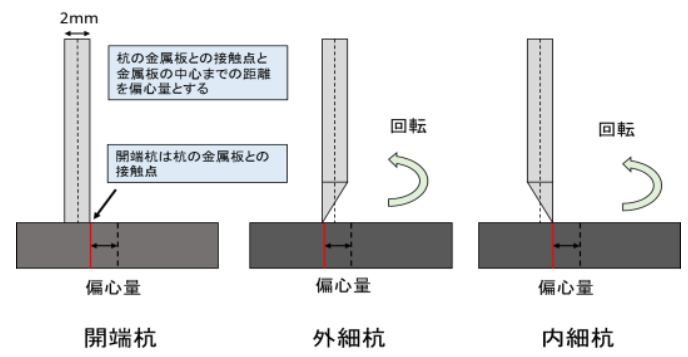

図-5＼cjkstart金属板の偏心量の定義

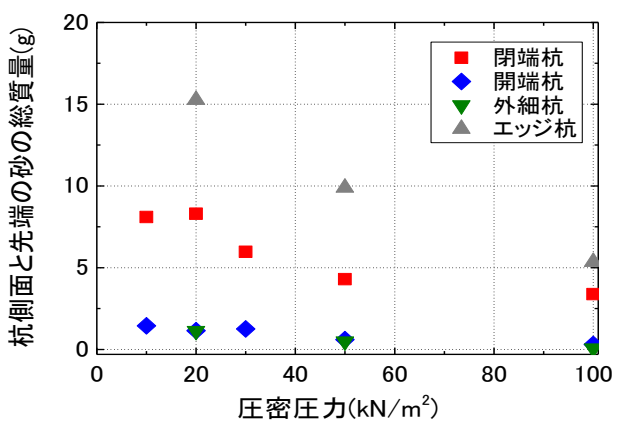

図-6 粘性土地盤の圧密圧力と粘性土に連込まれた砂の 総和の関係

り，いずれのケースにおいても圧密圧力が小さくなるほ ど砂の連込み量が多かった. 同じ形状の杭を用いた場合， 圧密圧力が $10 \mathrm{kN} / \mathrm{m}^{2}$ と $100 \mathrm{kN} / \mathrm{m}^{2}$ の場合の砂の連込み量 の差は 2 4 倍程度あった．また，同じ圧密圧力の条件で は閉端杭の方が開端杭よりも砂の連込夕量が多く，およ そ2〜5 倍程度の違いがあった. また，エッジ杭を用いた 場合が砂の連込み量が一番多くなる結果となった。

図-6に示した砂の連込み量は，杭の側面に連れ込まれ た砂と杭の先端で連れ込まれた砂の総和である。これら は実際には分離して測定されているので，それらを分け て示した結果を以下に示す.

図-7には連れ込まれて杭側面にあった砂の質量を示 した。 ここで，杭の側面での砂の連込みとは杭先端から 深さ方向に $8 \mathrm{~cm}$ 切り出した際の杭側面の粘性土に対寸 る連込み量である．図-7を見ると，圧密圧力が減少して いくと杭側面の砂の連込久が増加する傾向にあることが 分かる。

次に，杭の側面のどの深さにおいて砂が多く連込まれ たのかを示すために深度ごとの砂の連込久量の測定結果 を図-8 と図-9 に示す．図-8 は圧密圧力 $20 \mathrm{kPa}$ の粘土地 盤の場合の結果である. 図中の太い実線は層厚 $8 \mathrm{~mm}$ ご とに測定した砂の連れ込み量の深さ $1 \mathrm{~mm}$ あたりの平均 連込み量である．折れ線は，それを平均深さで代表させ てつないだものである．なお，深さの最も浅い部分の連 込みに関しては, 粘土層と砂層との境界部分にあたり, 粘土層が軟弱のため粘土層を乱してしまうおそれから表 層の砂を取り除くことができないため，表層に残った砂 と連れ込みの砂の区別ができなくなってしまう。そのた 


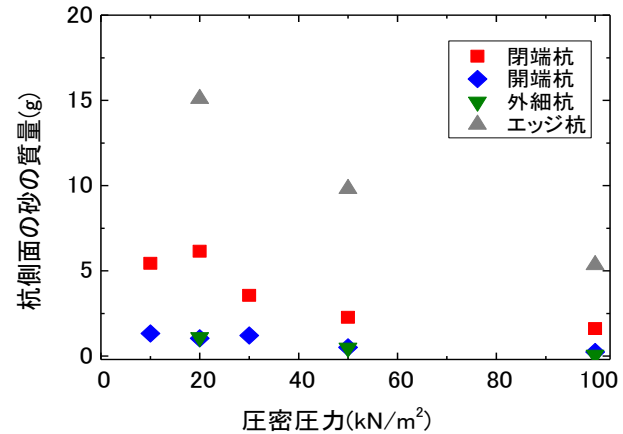

図-7 粘性土地盤の圧密圧力と粘性土に連込まれた杭側 面の砂の質量の関係

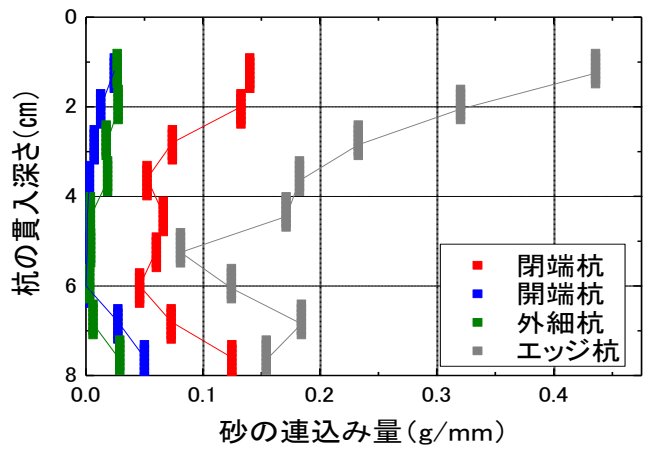

図-8 圧密圧力 $20 \mathrm{kPa}$ の粘性土地盤における貫入深さと 砂の連込み量の関係

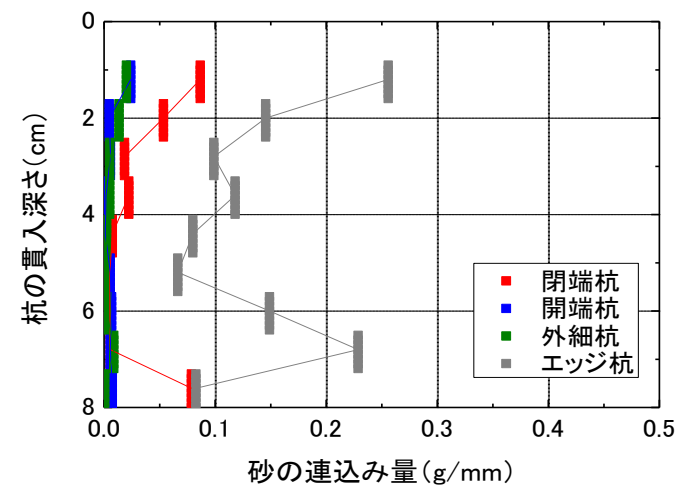

図-9 圧密圧力 $50 \mathrm{kPa}$ の粘性土地盤における貫入深さ 之砂の連込み量の関係

め，最も浅い部分にあたる粘土層表層から $0 \sim 0.8 \mathrm{~cm}$ ま での砂の連込みに関しては不明として，示していない， 図-8 を見ると, いずれの杭でも深度の浅い部分の砂の連 れ込み量が最も多くなっており，深度が深くなるにつれ て徐々に連込み量が減少していき，ある深さ付近で再び 連込み量が増加していく傾向にあった。

図-9には，圧密圧力 $50 \mathrm{kN} / \mathrm{m}^{2}$ の場合の結果を示寸. 粘 性土層の上面に近いほど砂の連込み量が多く，下層に行 くほど連れ込み量は小さくなるものの，下端部付近でま た，連れ込み量が多くなるという傾向は圧密圧力 20 $\mathrm{kN} / \mathrm{m}^{2}$ の時と同様であるが，全体として，連れ込み量が 小さくなっていることが分かる. 特に, 開端杭と外細杭 ではほとんど連れ込みが見られない状況にあった。

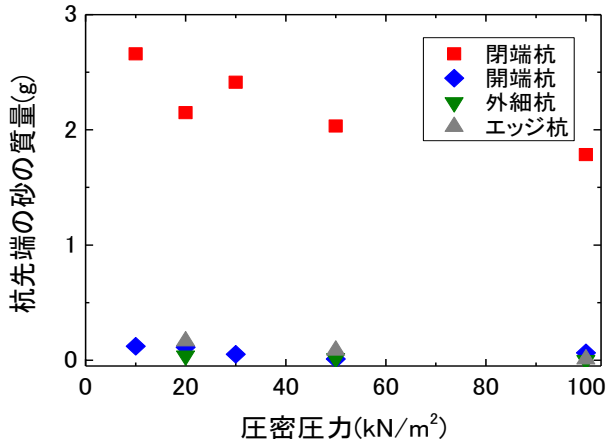

図-10 粘性土地盤の圧密圧力と粘性土に連込まれた杭 先端の砂の質量

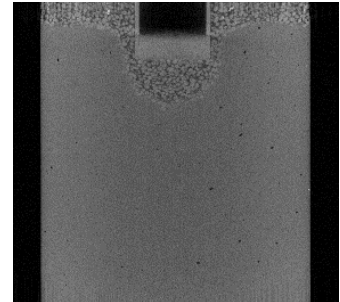

(a)圧密圧力 $10 \mathrm{kPa}$

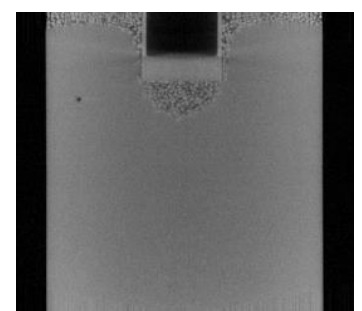

(b)圧密圧力 $100 \mathrm{kPa}$
図-11 粘性土地盤に閉端杭が貫入したときの杭先端の 状況 $(\mathrm{X}$ 線 CT による鉛直断面画像)

なお，図-8 と図-9で共通して，エッジ付きの連れ込み 量が多く，しかもかなり深いところまで連れ込む現象が みられているが，これは，エッジが杭の外側に突き出し ていることが原因である。粘性土が過圧密の条件である ため，エッジの上の部分に空洞ができ，そこに砂が落下 してくることが原因である．なお，実際の原位置地盤で は，正規圧密地盤であることから杭打設による空隙は早 期に閉塞寸る 4) と考えられるので，比較的小さなエッジ であれば，連れ込み量はそれほど大きくはならないと考 えられる，また，閉端杭では，開端杭よりも連れ込む量 が大きくなるのは，杭先端部に残る砂が徐々に側面に出 てくるためではないかと思われる。

図-10 に粘性土地盤の圧密圧力と粘性土に連込まれた 杭先端の砂の質量の関係を示した.ここで，杭先端に連 込まれた砂の連込みとは, 杭の先端より $1 \mathrm{~cm}$ 下までの部 分に連込まれた砂の質量である．図-10 を見ると，閉端 杭には杭先端に多くの砂の連込みが確認でき，その他と の差は歴然である．特に，圧密圧力が小さい程，砂の連 込み量が増加する傾向にある。

図-11 に粘性土の圧密圧力 $10 \mathrm{kPa}$ と $100 \mathrm{kPa}$ における 閉端杭を貫入した場合の X 線 CT による鉛直断面画像を 示寸．図-11 は砂層表面からの貫入深さが $70 \mathrm{~mm}$ の時の ものである．なお，上層の砂層の層厚はいずれも $50 \mathrm{~mm}$ であったこの画像からすると，圧密圧力 $10 \mathrm{kN} / \mathrm{m}^{2}$ の場 合には，粘性土層の上面が杭貫入に伴って低下したよう である．また，粘性土の圧密圧力 $10 \mathrm{kPa}$ のケースの方が 
圧密圧力 $100 \mathrm{kPa}$ の地盤に比べ，杭の先端部分に形成さ れるお椀型の楔の貫入方向の高さが大きいことが分かる. この違いは粘性土の剛性の違いによるものと考えられる. この二つのケースは圧密圧力の違いから粘性土地盤の剛 性が異なり，杭の貫入によって杭と粘性土地盤に挟まれ た砂が，粘土を押したときに圧密圧力が小さいほうが粘 土表面がよりたわみやすい状況になっていたため杭先端 の砂の大きさに違いが生じたと考えられる.

図-11 からすると，杭の先端には高さが杭径の 0.4 0.7 倍程度の長さでお椀状に砂が残るようである。つまり， 残った砂の体積は(0.2 0.35) DA 程度と考えられる.ここ で，D は杭径，A は杭の断面積である.この体積をもと に図-10 に示した閉端杭のケースでの砂の質量を概算す ると 2 3 g の砂が先端に残ることになる.このような簡 易な計算結果と図-10 に示した砂の量はおおむね同程度 であることから，杭寸法によらず図-11 に示したような 形状の砂が杭先端に残ることが想定される. 開端杭でも 相似的に同じような形状で砂が残るとして，D を杭の肉 厚, $\mathrm{A}$ を杭材部の断面積であるとして $0.35 \mathrm{DA} の$ 体積の 砂が残るとして概略計算をすると, $0.12 \mathrm{~g}$ 程度砂が先端 に残ることになる. これを仮に直径 $1000 \mathrm{~mm}$ 肉厚 $15 \mathrm{~mm}$ の鋼管杭を想定すると, $260 \mathrm{~g}$ 程度の廃棄物を連れ込むこ とになる，ただし，実地盤では，廃棄物層と粘性土の剛 性比がもつと小さくなるので，この数字の数倍程度まで は連れ込み量が増えることが想定される．仮に，図-1の (3や(4)のよに先を尖らせた杭でその先端部分にだけ廃 棄物が残るとすると, 連れ込む量は $250 \mathrm{~g}$ の 20 分の 1 10 分の 1 程度に減らすことも不可能ではないと考えられる.

\section{（2）杭の肉厚より大きな粒状廃棄物の連込み}

図-5 に示した偏心量と杭貫入に伴い粘性土中に連込 まれた金属板の貫入深さの関係を図-12 に示す. 実験で は 2 枚の金属板を貫入させたため各金属板の貫入深さを 白抜きのプロットで示し， 2 枚の平均值を色塗りのプロ ットで示している. 図-12 より, どの杭を用いた場合に も偏心量が小さい程貫入深さが深く，偏心量が大きくな ると貫入深さが浅くなる。このことは，偏心量が大きい 程浅い深さで金属板が杭から外れることを意味している。 開端杭における偏心量を変化させた複数のケースにおけ る金属板の貫入の状態をX線CT装置を使って観察した. 図-13 には粘性土への杭の貫入深さが $15 \mathrm{~mm}$ と $18 \mathrm{~mm}$ で の状態を示している. いずれの図とも左側の金属板の偏 心量は $2.55 \mathrm{~mm}$, 右側の偏心量は $0.78 \mathrm{~mm}$ である. 図-13 より, 偏心量の違いによって杭の貫入による金属板の傾 斜の度合いが異なっていることがわかる．特に，偏心量 が大きい場合の方が早期から金属板の傾斜が大きくなる 傾向にあった. 特に貫入深さ $18 \mathrm{~mm}$ では, 偏心量の大き い写真の左側の金属板に関して金属板と杭とが接してい
た部分がスライドし，金属板が杭の中心から外側に向か って逃げていくような滑動の挙動が起こっていた.

次に，金属板の角度や金属板が杭との設置点から外側 方向に滑り出す滑動距離を求めた．まず，杭の粘性土 の貫入量と金属板の傾斜角度の関係を図-14 に示す. 緑 で示した点は偏心量 $0.78 \mathrm{~mm}$ の時のものであり，赤，青 がそれぞれ偏心量 $2.01 \mathrm{~mm}$ と $2.55 \mathrm{~mm}$ の時の結果を示し ている. 図-14 から偏心量が少ない偏心量 $0.78 \mathrm{~mm}$ の場 合は，貫入量が大きくなっても金属板の傾斜角度が他の 二つのケースに比べると小さく，その後も小さい角度の まま貫入が進んでいた。 それに対し偏心量が $2 \mathrm{~mm}$ 以上 である二つのケースは貫入初期から偏心量に $0.78 \mathrm{~mm}$ に 比べ金属板の傾斜角度が大きくなって貫入が進んでいた。

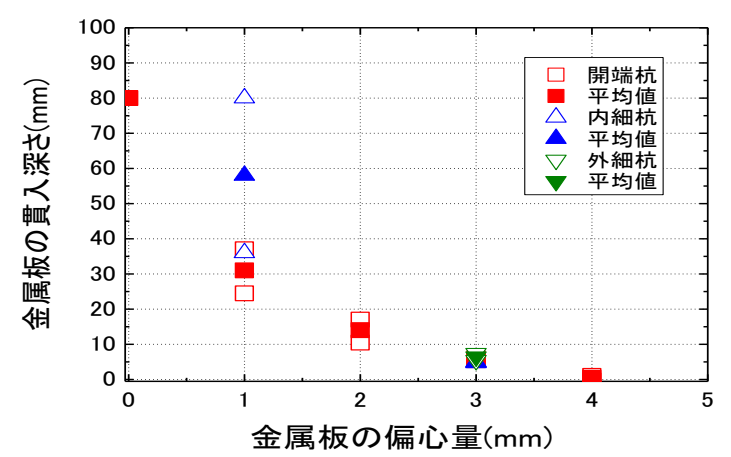

図-12 金属板の偏心量と粘性土地盤への貫入深さの 関係

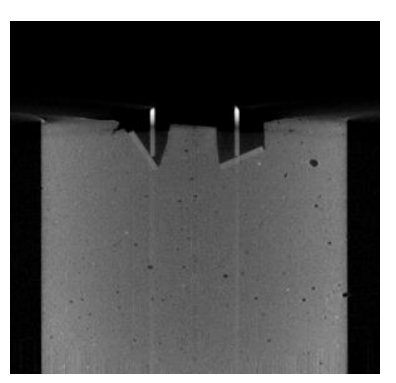

貫入深さ $15 \mathrm{~mm}$

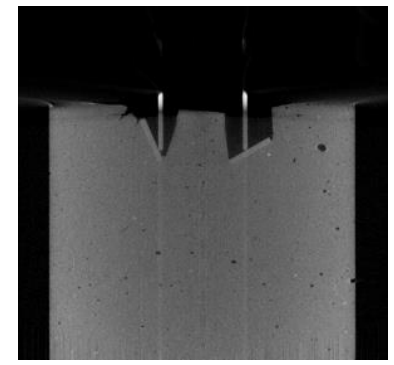

貫入深さ $18 \mathrm{~mm}$
図-13 粘土地盤に開端杭が貫入したときの杭先端の状 況(X 線 CT による鈆直断面画像)

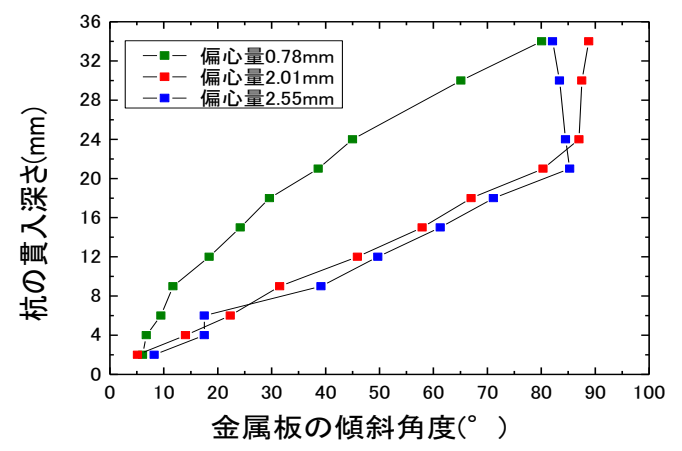

図-14 金属板の傾斜角度と杭の貫入深さの関係 


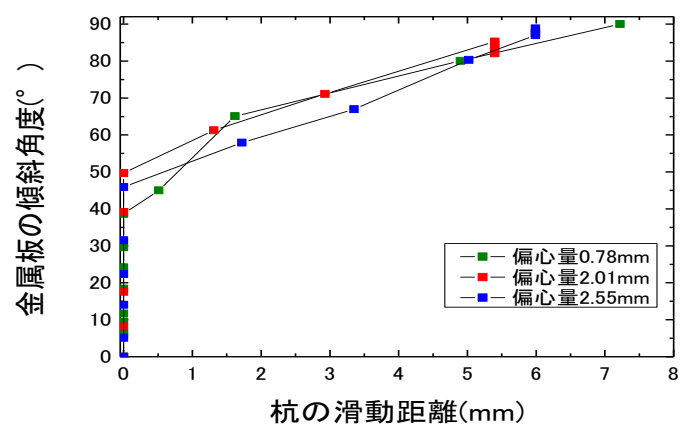

図-15 金属板の傾斜角度と滑動距離の関係

先に述べたように X 線 CT による画像から金属板があ る程度傾斜すると金属板が杭から滑り出し，外側へ滑動 寸る現象が見られた．そこで図-15に金属板の傾斜角度 と滑動距離の関係を示した.ここでの滑動距離とは，金 属板の杭との貫入初期の接触位置から，金属板の滑動が 発生し外側方向に滑り出した金属板の水平方向の移動距 離とする。先ほどの図-14 と同様に三種類の偏心量をそ れぞれ色分けしてプロットしている。ここでは，貫入を 止めて X 線 CT による撮影を行ったため，連続デー夕は とれていない，そのため，滑動が発生した厳密な傾斜角 度の算出はできていない．図-15 を見ると偏心量が異な る全てのケースにおいて金属板の傾斜角度が $40 \sim 50^{\circ}$ の範囲内において金属板の滑動が発生していることが分 かる．さらに，滑動が発生した後も滑動距離と傾斜角度 の関係はおおむ斿等しい傾向を示していることが分かる。 このことから，金属板の傾斜角度がある一定以上大きく なることで滑動が発生する可能性があることが分かった。

\section{4. 結論}

本研究では，廃棄物層を貫通して打設される杭が廃棄 物を下層の粘性土地盤に連れ込む挙動について検討した. 杭の肉厚よりも小さな粒径を持つ廃棄物については，砂 でモデル化し，粘性土地盤と廃棄物地盤の岡性の違いに 着目するために，粘性土地盤の圧密圧力を変えて実験を 行った。 その結果，粘性土の圧密圧力が小さい程，全体 的な砂の連込み量が大きくなる傾向にあることが分かっ た．また，杭の肉厚より大きな廃棄物の連込みについて は，金属板でモデル化し金属板に作用する杭の貫入力の 偏心量の違いの影響を検討した．金属板は偏心量が大き い程，杭の貫入深さが浅いところで回転し始め杭から外 れるのも貫入深さの浅いところとなることが分かった.

\section{参考文献}

1) 片山廣明, 手塚博治, 山下公平:廃棄物処分場における 三重管基礎杭，橋梁と基礎，第 42 巻第 4 号, pp.43-46, 2008.

2) 菊池喜昭, 橋爪秀夫 : 杭周辺地盤の透水性に関する室内 透水試験, 第 6 回環境地盤工学シンポジウム, pp. 217224, 2005.

3）嘉門雅史，勝見武，乾徹，濱田悟 : 鋼管杭打設粘土地盤 と杭境界面における漏水量とその評価, 材料別冊, 第 54 巻，第 11 号，pp.1100-1104， 2005.

4) 菊池喜昭, 菅野高弘: 海面廃棄物処分場の遮水基盤を貫 通する杭の施工可能性に関する研究, 地盤工学会誌, 第 56 巻第 8 号, pp.28-29, 2008.

5) 平尾隆行 : 海面処分場跡地の高度利用のための基礎杭 打設工法に関する研究，東京理科大学学位申請論文, $226 \mathrm{p}, 2018$.

6) 渡部要一，水谷崇亮，金子崇，増門孝一：海面処分場に おける杭基礎の適用性一未処理廃棄物地盤における打 設実験と杭周面透水試験一, 港湾空港技術研究所資料, No.1321， 34p, 2016.

(2018.2.8受付)

\title{
MECHANISM OF GRANULUR WASTE DRAGGING BY PILE DRIVING THROUGH WASTE LANDFILL
}

\author{
Riki NOMURA, Yoshiaki KIKUCHI, Taichi HYODO, Shunsuke NOBATA, \\ Takayuki HIRAO, Makoto TAKEMOTO, and Satoshi MATUMURA
}

In order to use the premises of the off shore waste disposal site highly, it is necessary to construct piles into the bearing layer. In such a case, piles penetrate through impermeable layer. At that time, the pile is thought to bring the waste below the impermeable layer. In this study, for the waste of small particle size, the influence of the difference in rigidity between waste layer and underlying impermeable layer on waste dragging was investigated. For the waste of large grain size, the difference of bringing in due to the difference in eccentricity was investigated. As a result of experiments, it was confirmed that in the case of small particle size waste, the rigidity of the impermeable layer relatively decreases, so that the amount of waste brought increases, in the case of large grain waste, the penetration depth was found to be different according to the difference of eccentricity. 